\title{
Perturb/Observe Controller and PI Controller for Battery Charger with Photovoltaic Panel
}

\author{
Fatma Aslan \\ Department of Energy Systems Engineering, Institute of Sciences, \\ Bilecik Seyh Edebali University, Bilecik, Turkey \\ E-mail: faatmaslan@gmail.com \\ Yasemin Onal (Corresponding author) \\ Department of Electrical and Electronics Engineering, \\ Bilecik Seyh Edebali University, Bilecik, Turkey \\ E-mail: yasemin.onal@bilecik.edu.tr
}

\begin{abstract}
In this study, the Perturb observe controller and PI controller for a Li-Ion battery charger with photovoltaic panel sourced is proposed. Compared with other batteries, Lithium-Ion (Li-Ion) batteries are featured by high-energy, high-power, long-life and environmental-friendliness and therefore have found wide application in the consumer electronics. The voltage and current of PV panels are nonlinear and variable environmental conditions cause to change voltage and current. They also cause to change maximum available power of PV panels. Maximum power point tracking (MPPT) methods are used to obtained maximum power and to increase efficiency of the photovoltaic panels (PV). The charger topology consists of two-stages: 1) a photovoltaic panel source DC-DC boost converter to obtain the high output voltage, and 2) a half-bridge bidirectional DC-DC buck-boost converter to behave as a charge controller. The perturb and observe $(\mathrm{P} \& \mathrm{O})$ controller is used to obtained maximum power and voltage of the photovoltaic panel (PV) system. The constant voltage method with PI controller is used for bidirectional DC-DC buck-boost converter to charge of a Li-Ion battery. PI controller is a simple technique and also it provides satisfactory results. The simulation of the $5 \mathrm{~kW}$ photovoltaic panel, DCDC boost converter and charger are created by using of computational blocks and design suit blocks in PSIM circuit simulations.
\end{abstract}

Keywords: Photovoltaic panel, Battery charger, MPPT controller, DC-DC boost converter, Lithium-Ion batteries

DOI: $10.7176 / \mathrm{JSTR} / 5-12-19$

\section{Introduction}

In recent years, inadequate of fossil fuel sources, increases in energy requirements and air pollution have increased the number of studies on renewable energy sources. Photovoltaic (PV) systems come to the forefront as they are clean energy sources, natural resources and they can generating electrical energy from sunlight everywhere. [1-3]. The disadvantage of PV systems is that the sun does not shine in the same way for 24 hours a day, when the radiation of the sun decreases, PV panels stop generating electricity. In addition, the efficiency of generating electricity from PV system is very low, especially in low solar radiation areas.

Due to the nonlinear relationship between current and voltage of PV system, it can be seen that there is a unique maximum power point (MPP)[4]. Therefore, monitoring the MPP tracking (MPPT) is an important part of the PV system. PV panels are grouped in larger units called PV modules that are also connected together in a parallel series configuration to form PV arrays. MPPT methods use voltage and current value obtained from PV panels and regulate the duty cycle of Pulse width Modulation PWM of active switches to DC-DC converters. After boost converter, current and voltage change constantly because of changing environmental conditions. The DC-DC converter such as boost converter, buck converter buck-boost converter SEPIC converter is designed to be connected directly to the photovoltaic panel and can be operated to search for the MPPT[5-7].

Several algorithms of MPPT method are developed in the literature. Some of these algorithms is perturb 
and observe P\&O [8-9], incremental conductance [10-11], fuzzy logic (FLC) [12], fractional open-circuit voltage and fractional short-circuit current algorithms [13-14]. The P\&O algorithm is generally used, due to its ease of implementation. If the output voltage of the PV array is perturbed in a given direction and if the output power of the PV array increases, the operating point has moved toward the MPP and the output voltage must be further perturbed in the same direction. Otherwise, if the output power of the PV array decreases, the operating point has moved away from the MPP and the direction of the operating voltage perturbation must be reversed. To charge a Li-Ion battery there are some methods in the literature. These methods are constant current and constant voltage methods [15-16]. The battery charges in constant current and in appropriate voltage. To provide constant current and appropriate voltage for battery, PI controller applied buck DC-DC after boost DC-DC.

In this study, control system of a two stage topology with connected the photovoltaic panel supported boost DC-DC converter and bidirectional DC-DC buck-boost converter is proposed for Li-Ion battery charger. In the first stage, the $\mathrm{P} \& \mathrm{O}$ controller is used to obtained maximum power and voltage of the photovoltaic panel (PV) system. In the second stage, the charging and discharging of a battery charger system is performed. The constant current and voltage method with PI controller is used for bidirectional DC-DC buck-boost converter to charge of a Li-Ion battery. PI controller is a simple technique and also it provides satisfactory results. The simulation circuit of the $5 \mathrm{~kW}$ charger system is created by using of computational blocks and design suit blocks in PSIM circuit simulations.

\section{Charger Circuit Topology}

2.1 The photovoltaic panel supported DC-DC boost converter

Fig. 1 shows the photovoltaic panel supported DC-DC boost converter circuit.

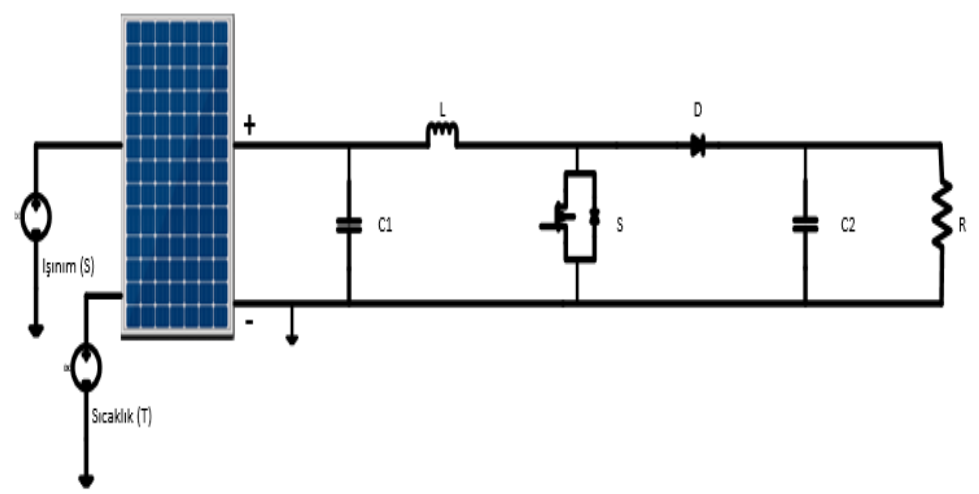

Figure 1. The photovoltaic panel supported DC-DC boost converter

PV panel generates to electricity from sun light. An PV panel is modeled by a current source in parallel with a diode. The shunt and series resistances equivalent circuit of PV panel are added to the model as shown in Fig. 2. $R_{P}$ is the equivalent shunt resistance and $R_{S}$ is the series resistance [17].

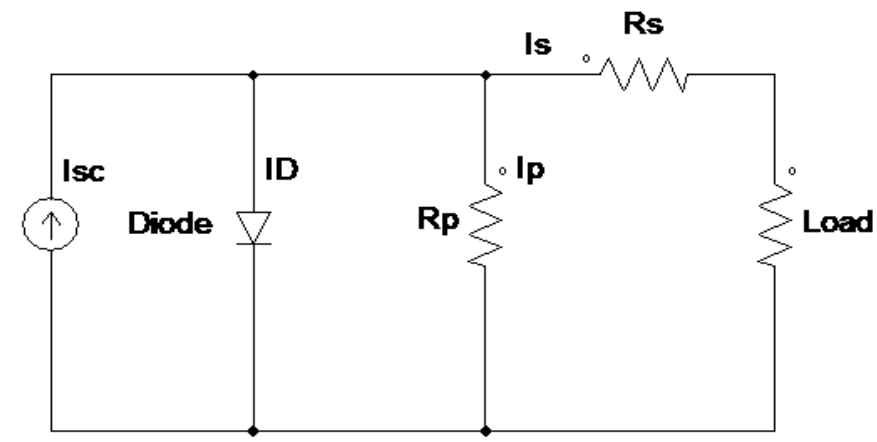

Figure 2. The equivalent circuit of PV panel

From the equivalent circuit, the output current formula for PV is calculated using Eq. 1, Eq. 2 and Eq. 3.

$I_{\text {out }}=I_{s c}-I_{\mathrm{D}}$ 
$I_{D}=I_{0} *\left(e^{\frac{q\left(V+R_{S} I\right)}{n \mathrm{~K} T}}-1\right)$

$I_{\text {out }}=I_{L}-I_{0} *\left(e^{\frac{q\left(V+R_{S} I\right)}{n \mathrm{KT}}}-1\right)-\frac{V+R_{S} * I}{R_{\mathrm{p}}}$

Where $\mathrm{I}_{\mathrm{L}}$ is the current of PV cell, $\mathrm{I}_{0}$ is the PV cell reverse saturation current, q means the electron charge $\mathrm{K}$ is the Boltzmann's constant $\left(1.38 \times 10^{-23} \mathrm{~J} / \mathrm{K}\right)$, T is the temperature of the PV panel, $\mathrm{n}$ is the P-N junction curve constant, $\mathrm{V}$ voltage applied to the load, $\mathrm{q}$ is elementary charge $\left(1.602176565 \times 10^{-19}\right)$. The power produced by a PV cell is so low (1-1.5 W) so to get desired power, solar cells are connected series or parallel [12]. The parameter of PV panel is given in Table 1. Number of PV in series is seven and number of PV in parallel is four. Light intensity value is $1000 \mathrm{~W} / \mathrm{m}^{2}$. The ambient temperature input is $25 \mathrm{C}^{\circ}$.

Table 1. PV panel parameters

\begin{tabular}{|l|l|l|}
\hline PV Panel & $\mathrm{N}_{\mathrm{s}}$ & $72 * 7$ \\
\hline Number of Cells & $\mathrm{S}$ & $1000 \mathrm{~W} / \mathrm{m}^{2}$ \\
\hline Light Intensity & $\mathrm{T}$ & 25 \\
\hline Temperature & $\mathrm{R}_{\mathrm{s}}$ & $0.0075 / 4 \Omega$ \\
\hline Series Resistance & $\mathrm{R}_{\mathrm{sh}}$ & $1000 / 4 \Omega$ \\
\hline Shunt Resistance & $\mathrm{I}_{\mathrm{sc}}$ & $5.65 * 4 \mathrm{~A}$ \\
\hline Short Circuit Current & $\mathrm{I}_{\mathrm{s}}$ & $9.54 \mathrm{e}-9 * 4 \mathrm{~A}$ \\
\hline Saturation Current & $\mathrm{E}_{\mathrm{g}}$ & 1.12 \\
\hline Band Energy & $\mathrm{A}$ & 1.2 \\
\hline Ideality Factor & $\mathrm{C}_{\mathrm{t}}$ & $0.002825 * 4$ \\
\hline Temperature Coefficient & $\mathrm{K}_{\mathrm{s}}$ & 0 \\
\hline Cofficient & & \\
\hline
\end{tabular}

The DC-DC boost converter increase PV panel's output voltage and power. There are two modes of operation of the boost converter depending on opening and clothing of the electronic switch [18]. Fig. 3a and Fig. $3 \mathrm{~b}$ show the operation modes. When $\mathrm{S}$ switch is on at $\mathrm{t}=0$, the diode is off and the current passes through the inductor L. the energy is stored in inductor and the current increases linearly. This operation mode is shown Fig. 3a. When the $\mathrm{S}$ switch is off at $\mathrm{t}=t_{\text {on }}$, a diode is on and the sum of energy is stored in the inductor and the input current is flowed through the $\mathrm{C}_{2}$ capacitor. The energy is stored in the $\mathrm{C}_{2}$ capacitor. The capacitor voltage is transferred the load $\mathrm{R}_{\mathrm{y}}$. The inductor current decreases until the $\mathrm{S}$ switch is turned on. This operation mode is shown in Fig. $3 \mathrm{~b}$.

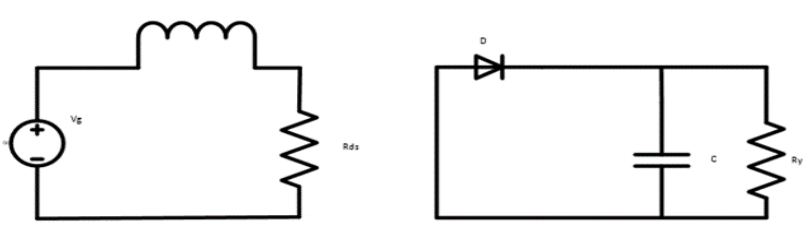

(a) Mode1

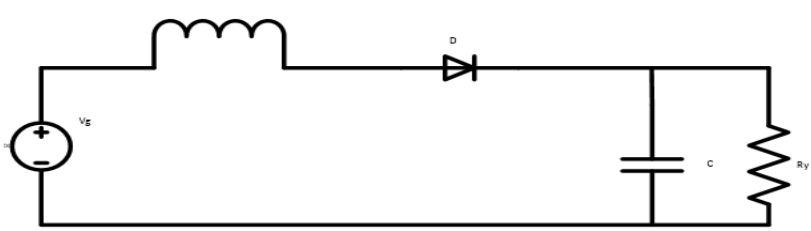

(b) Mode2

Figure 3. The DC-DC boost converter operation mode

The output voltage of DC-DC boost converter is calculated using Eq. 4 [19]. 
$\mathrm{V}_{\mathrm{o}}=\frac{\mathrm{V}_{\mathrm{s}}}{1-\mathrm{D}}$

$\mathrm{D}=\frac{t_{\text {on }}}{T}$

$\mathrm{T}=1 / F_{S}$

where $\mathrm{D}$ is duty cycle, $\mathrm{V}_{\mathrm{o}}$ is average output voltage, input voltage is $\mathrm{V}_{\mathrm{s}}, t_{\text {on }}$ is the switching on time, $\mathrm{T}$ is the switching period, $F_{S}$ is the switching frequency.

The DC-DC boost converter output voltage was calculated in Eq. (4) and the output L was calculated in Eq. (7). Where $\Delta I_{L}$ is ripple current of $\mathrm{L}, \mathrm{f}$ is frequency.

$L=\frac{V_{S} \cdot D(1-D)}{f_{S} \Delta I_{L}}$

The output $\mathrm{C}$ was calculated in Eq. (8). In there $\Delta I_{C}$ is ripple current of C.

$C=\frac{I_{o} \cdot D}{f_{S} \Delta I_{C}}$

This S switch was controlled by PWM signals which are generated from MPPT controller.

\subsection{The bidirectional DC-DC buck-boost converter}

Fig. 4. shows the bidirectional DC-DC buck-boost converter. Bidirectional converter topology is basic circuit of DC-DC converter. It is the anti-parallel combination of buck-boost converters. During the stepup operation $\mathrm{Q}_{3}$ is conduct according to the duty cycle whereas $\mathrm{Q}_{4}$ will not conduct in this mode. In step down mode $\mathrm{Q}_{4}$ will conduct according to the duty cycle and $\mathrm{Q}_{3}$ will not conduct in this mode. A small dead time provided between both the operations so that cross conduction can be avoided [9].

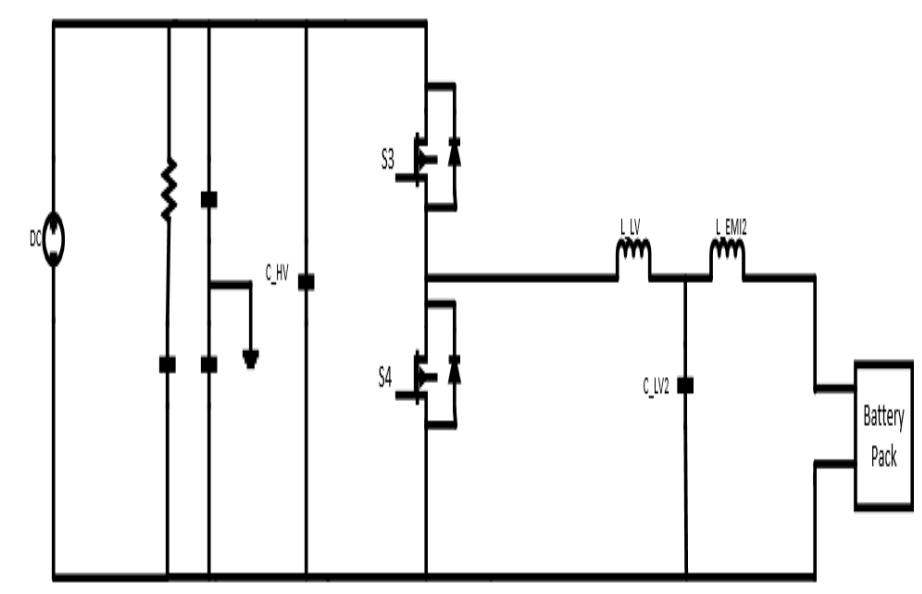

Figure 4. The Bidirectional DC-DC buck-boost converter

\section{Proposed Control Method}

To produce the switching signals used MPPT controller for the DC-DC boost converter. PV output voltage and current depend on solar irradiance and temperature. To obtain maximum efficiency from PV panel, of MPPT method is widely used. There are different MPPT methods. If PV curve $(\mathrm{dP} / \mathrm{dV}=0$, $\mathrm{dP} / \mathrm{PI}=0$ ) is zero, this point is defined MPP. In this study, Perturb and Observe P\&O algorithm from MPPT methods to control active switch. This algorithm is based on PV panel voltage and current measurement. A perturb leads to change in the output power of DC-DC boost converter. If the change in power is positive, then step will continue to same direction. If it is negative, then the step will continue on the contrary. Until the MPP has reached, this process continues [20-21]. Fig. 5 shows block schema P\&O controller for PV panel supported DC-DC boost converter. 


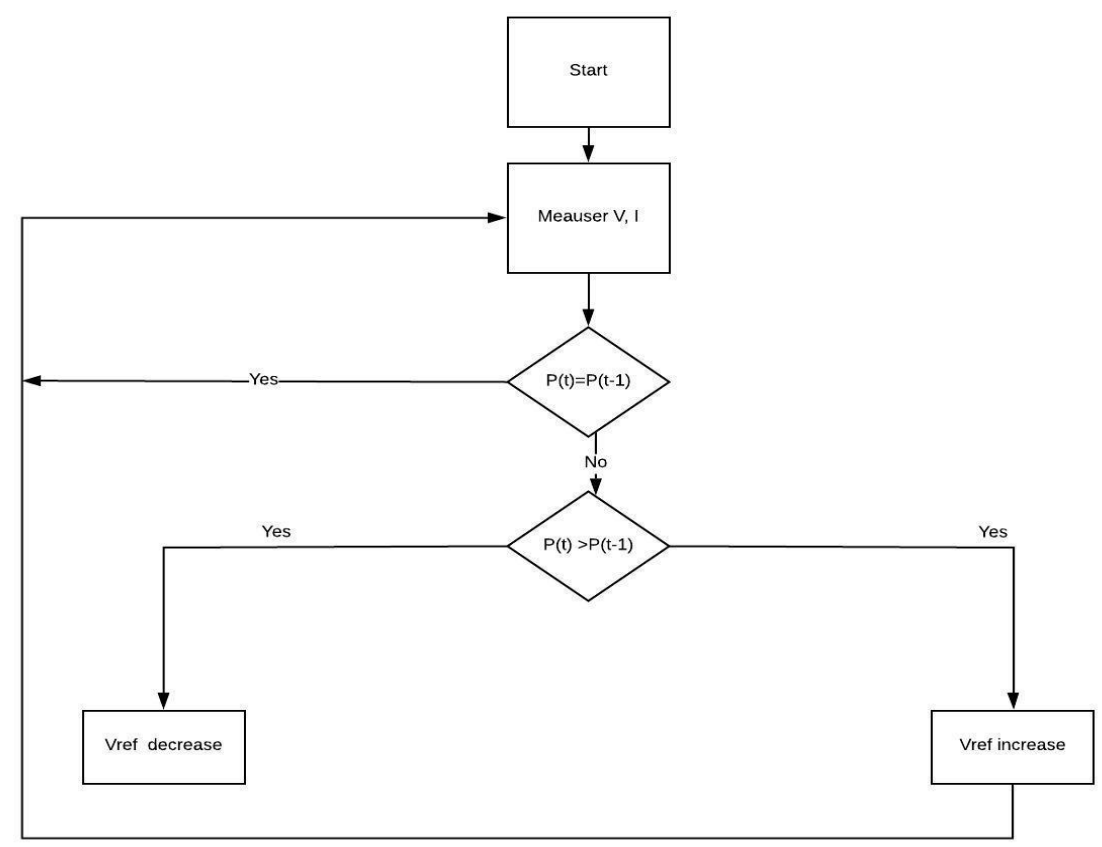

Figure 5. Block schema P\&O controller for PV panel supported DC-DC boost converter

Fig. 6 shows the block scheme of bidirectional DC-DC buck-boost converter control algorithm. The charge block implements constant voltage or constant current battery charging. When the battery voltage is less than the battery float voltage, it is constant current charging. The outer voltage loop is used is disabled and the inner current loop used PI control charges the batteries at a constant current rate. The parts of PI controller are integral gain and proportional gain. Ziegler-Nichols method used to determine the proportional gain $\mathrm{K}_{\mathrm{p}}$ and integral gain $\mathrm{K}_{\mathrm{i}} . \mathrm{K}_{\mathrm{p}}$ is effective to reduce the step up time $\mathrm{K}_{\mathrm{i}}$ is effective to eliminate steady state error. When the battery voltage reaches the battery float voltage, it is constant voltage charging. The outer voltage loop used PI control generates the current reference for the inner current loop to regulate the output voltage and power of buck converter. Discharge block implements constant-voltage or constant current discharging control to a battery. When the discharge control mode is set to voltage mode, the bidirectional converter regulates the DC bus voltage and the voltage loop used PI controller generates the reference for the current loop. When the discharge control mode is set to current mode, the bidirectional the converter regulates the current flowing into the DC bus to the maximum current that the converter can deliver.

\section{Results and Discussion}

The simulation model of controller shows in Fig. 7. The parameters of the power circuits for battery charger system are described in Tables 2, Tables 3 and Tables 4.

To confirm the validity of the used $\mathrm{P} \& \mathrm{O}$ controller and charger controller blocks, a simulation circuit has been performed using computational blocks and control suite block in PSIM. The simulation applied on three modes. These are charge mode, discharge current mode and discharge voltage modes.

Table 2. Parameters of the DC-DC boost converter

\begin{tabular}{|l|c|l|}
\hline \multicolumn{3}{|l|}{ The DC-DC boost converter } \\
\hline Input voltage & $\mathrm{V}_{\mathrm{s}}$ & $250 \mathrm{~V}$ \\
\hline Output resistance & $\mathrm{Ro}$ & $47 \Omega$ \\
\hline Input inductor & $\mathrm{L}$ & $4 \mathrm{mH}$ \\
\hline Input capacitor & $C_{1}$ & $470 \mathrm{uF}$ \\
\hline Output capacitor & $C_{2}$ & $1000 \mathrm{uF}$ \\
\hline Sampling frequency $\mathrm{f}_{\text {line }}(\mathrm{Hz})$ & $\mathrm{f}_{\mathrm{sw}}$ & $50 \mathrm{kHz}$ \\
\hline Output voltage & $\mathrm{V}_{\mathrm{dc}}$ & $500 \mathrm{~V}$ \\
\hline
\end{tabular}



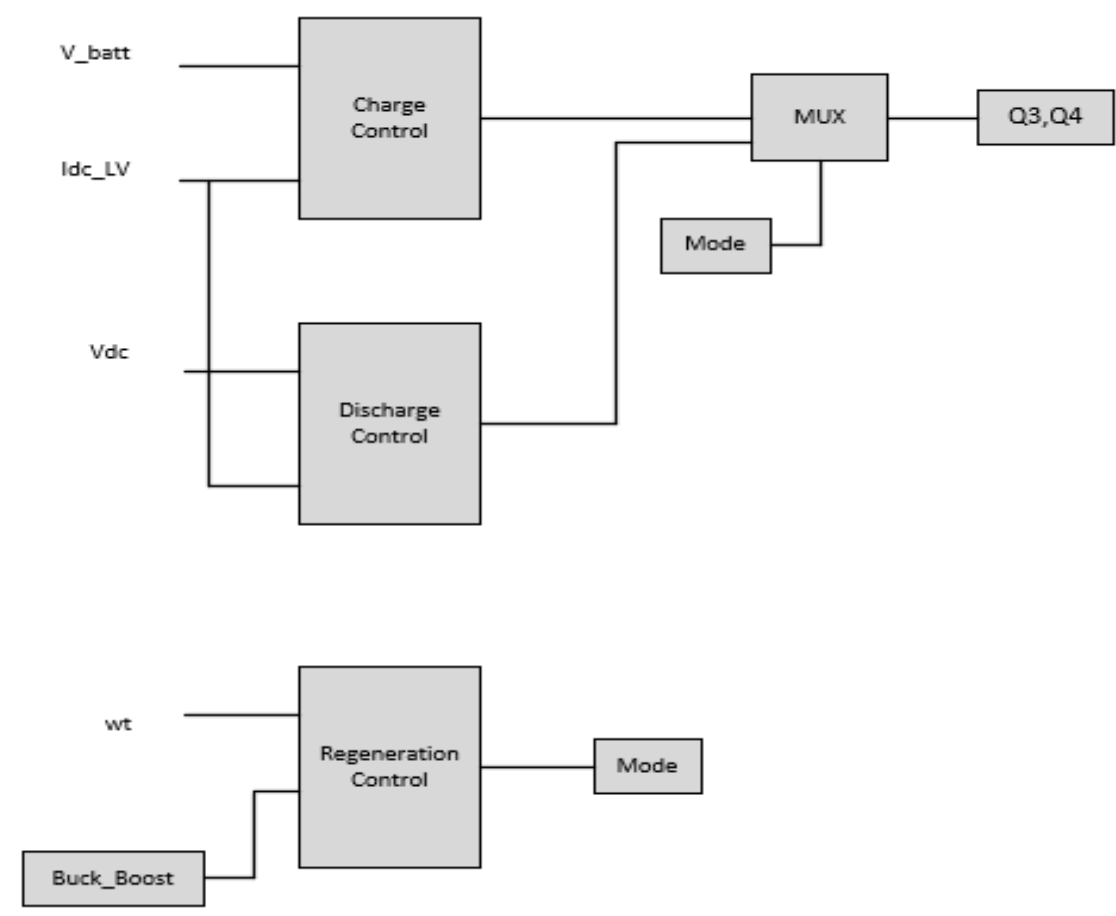

Figure 6. The block scheme of bidirectional DC-DC buck-boost converter control algorithm.

Table 3. Parameters of battery

\begin{tabular}{|c|c|c|}
\hline \multicolumn{3}{|l|}{ Battery } \\
\hline Battery power & $P_{\text {bat }}$ & $5 \mathrm{~kW}$ \\
\hline Battery voltage & $\mathrm{V}_{\text {bat }}$ & $200 \mathrm{~V}$ \\
\hline Battery resistance & $\mathrm{R}_{\text {bat }}$ & $0.05 \Omega$ \\
\hline Series cells numbers & $\mathrm{N}_{\mathrm{s}}$ & 60 \\
\hline Parallel cells numbers & $\mathrm{N}_{\mathrm{p}}$ & 12 \\
\hline Full battery voltage & $\mathrm{V}_{\text {bat }}$ & $4.2 \mathrm{~V}$ \\
\hline Battery sampling frequency & $f_{\text {bat }}$ & $20 \mathrm{kHz}$ \\
\hline
\end{tabular}

Table 4. Parameters of bidirectional DC-DC buck-boost converter

\begin{tabular}{|l|c|l|}
\hline Bidirectional DC-DC buck-boost converter \\
\hline Buck-Boost input capacitor & $\mathrm{C}_{\mathrm{HV}}$ & $1 \mathrm{uF}$ \\
\hline Buck-Boost output capacitor & $\mathrm{C}_{\mathrm{LV}}$ & $10 \mathrm{mF}$ \\
\hline Buck-Boost EMI filter inductor & $\mathrm{L}_{\mathrm{EMI}}$ & $10 \mathrm{uF}$ \\
\hline Buck-Boost output inductor & $\mathrm{L}_{\mathrm{LV}}$ & $0.8 \mathrm{mH}$ \\
\hline
\end{tabular}




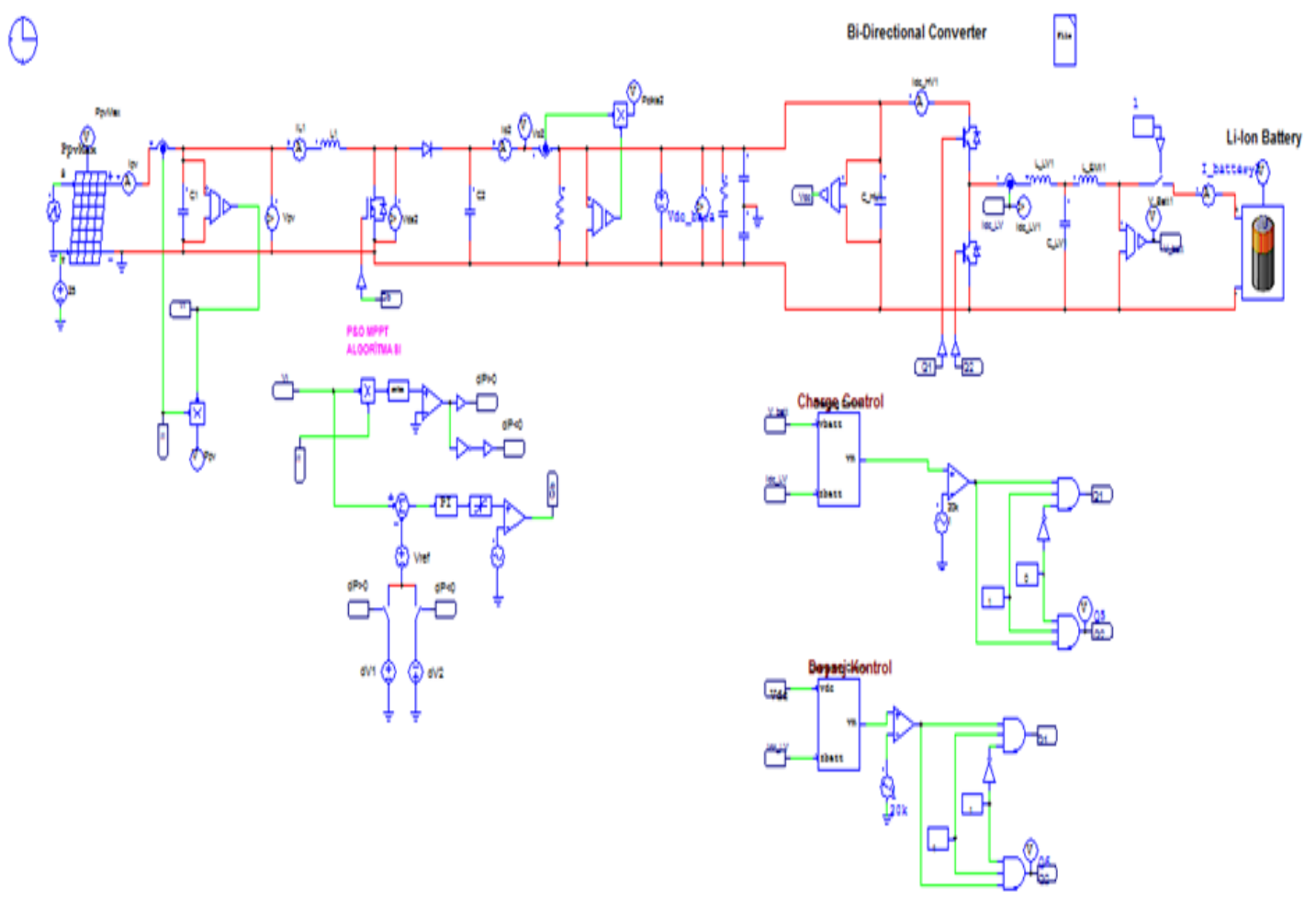

Figure 7. The simulation model of Photovoltaic Panel Supported Battery Charge/Discharge Control Circuit

In the charge control mode, the $\mathrm{P} \& \mathrm{O}$ controller is applied for $\mathrm{PV}$ panel supported DC-DC boost converter and the PI controller is applied for bidirectional DC-DC converter. The simulation results of the PV panel supported DC-DC boost converter for battery charge is shown in Fig. 8. $\mathrm{i}_{\mathrm{pv}}$ is the current signal of PV panel, $\mathrm{V}_{\mathrm{pv}}$ is output voltage signal of $\mathrm{PV}$ panel, $\mathrm{P}_{\mathrm{pvmax}}$ is output power signal of $\mathrm{PV}$ panel, $\mathrm{P}_{\text {out }}$ is output power signal of DC-DC boost converter, $\mathrm{V}_{\mathrm{dc}}$ is output voltage signal of DC-DC boost converter. According to simulation results $V_{p v}$ is $250 \mathrm{~V}, i_{p v}$ is $21 \mathrm{~A}, V_{d c}$ is $500 \mathrm{~V}, P_{\text {out }}$ is $5 \mathrm{~kW}, P_{p v \max }$ is $5,2 \mathrm{~kW}$, approximately. The simulation results of bidirectional DC-DC converter for the battery charger is shown in Fig. 9 . When the battery voltage reaches $250 \mathrm{~V}$ constant voltage, battery current changes from $-80 \mathrm{~A}$ to $30 \mathrm{~A}$. 

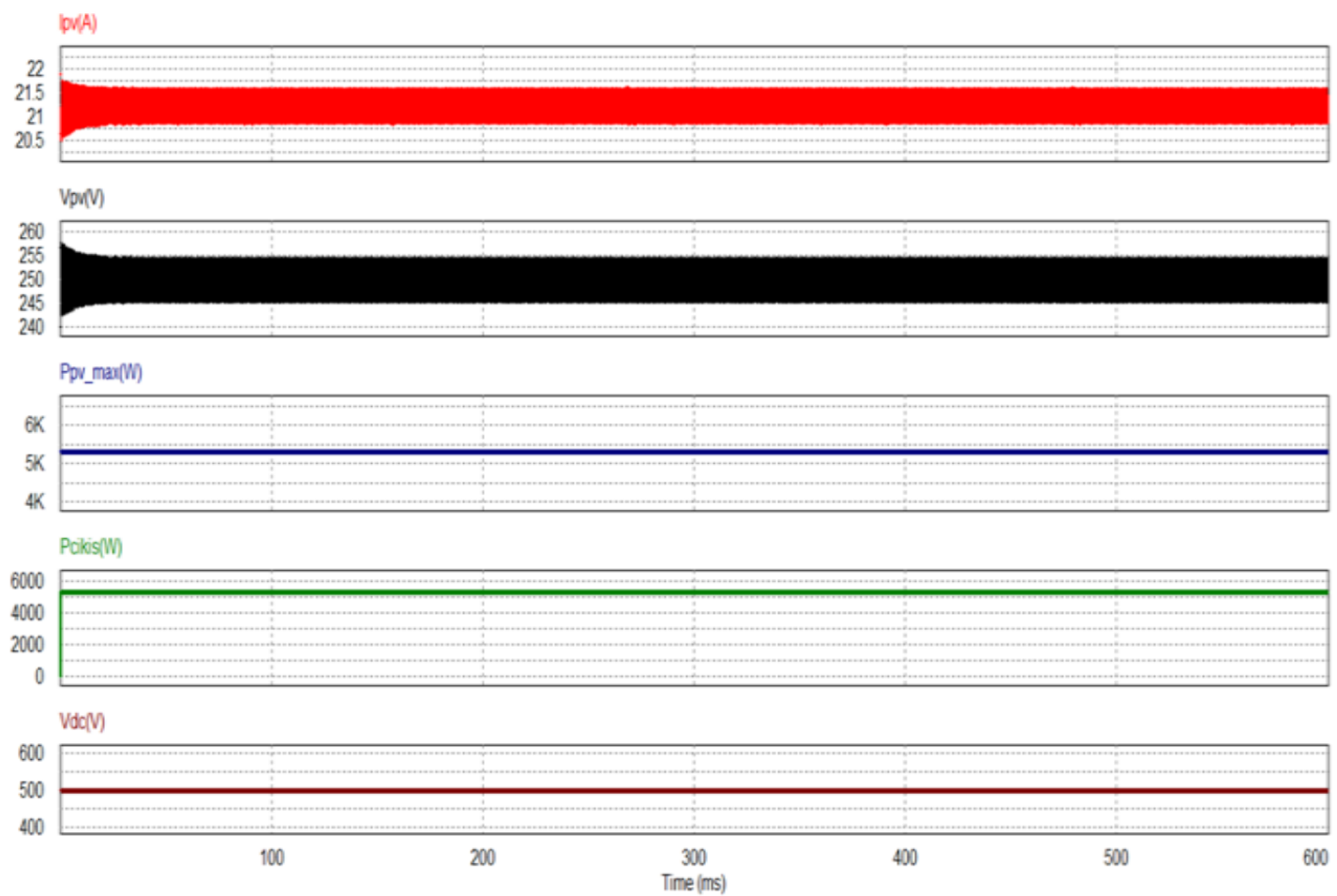

Figure 8. The simulation results for the PV panel supported DC-DC boost converter for battery charge

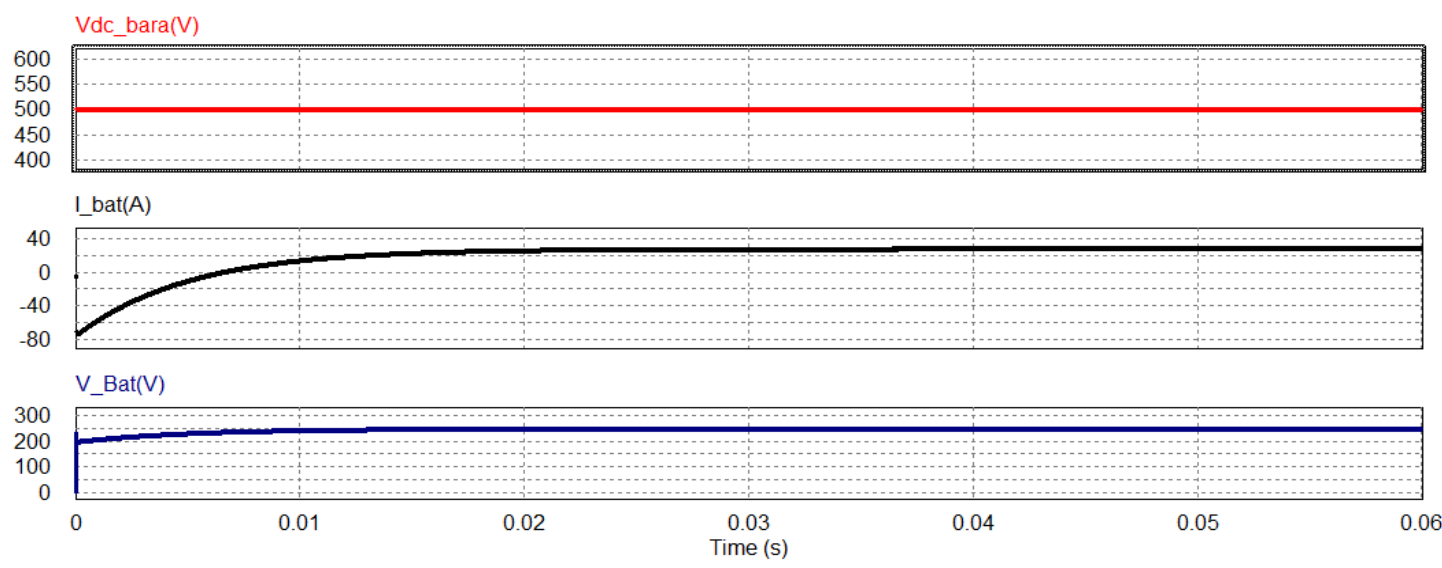

Figure 9. The simulation results of bidirectional DC-DC buck-boost converter for the battery charger

The discharge current mode is applied for battery. The simulation results of the PV panel supported DCDC boost converter for battery discharge current mode is shown in Fig. 10. In the Fig. 10, the current of $\mathrm{PV}$ panel is $21.25 \mathrm{~A}$, the output voltage of $\mathrm{PV}$ panel is $250 \mathrm{~V}$, the output max power of $\mathrm{PV}$ panel is $5 \mathrm{~kW}$. Fig. 11 shows simulation results of the bidirectional DC-DC buck-boost converter for battery discharge current mode. In the Fig. 11, the DC output voltage of boost converter is $500 \mathrm{~V}$ and the bidirectional DCDC converter regulates the current $-30 \mathrm{~A}$ flowing into the DC bus to the maximum current in the battery voltage $220 \mathrm{~V}$ 


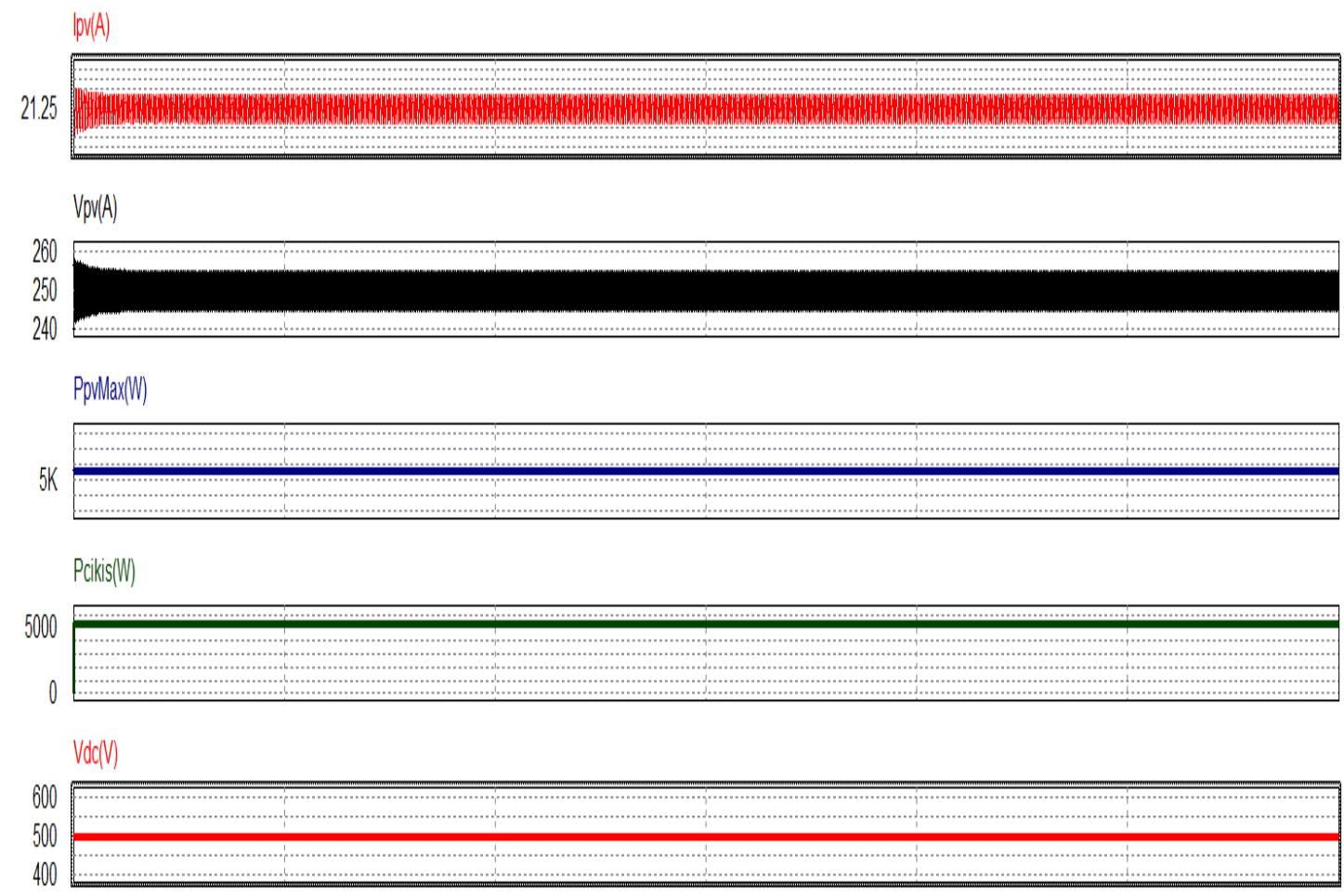

Figure 10. The simulation results for the PV panel supported DC-DC boost converter for battery discharge current mode

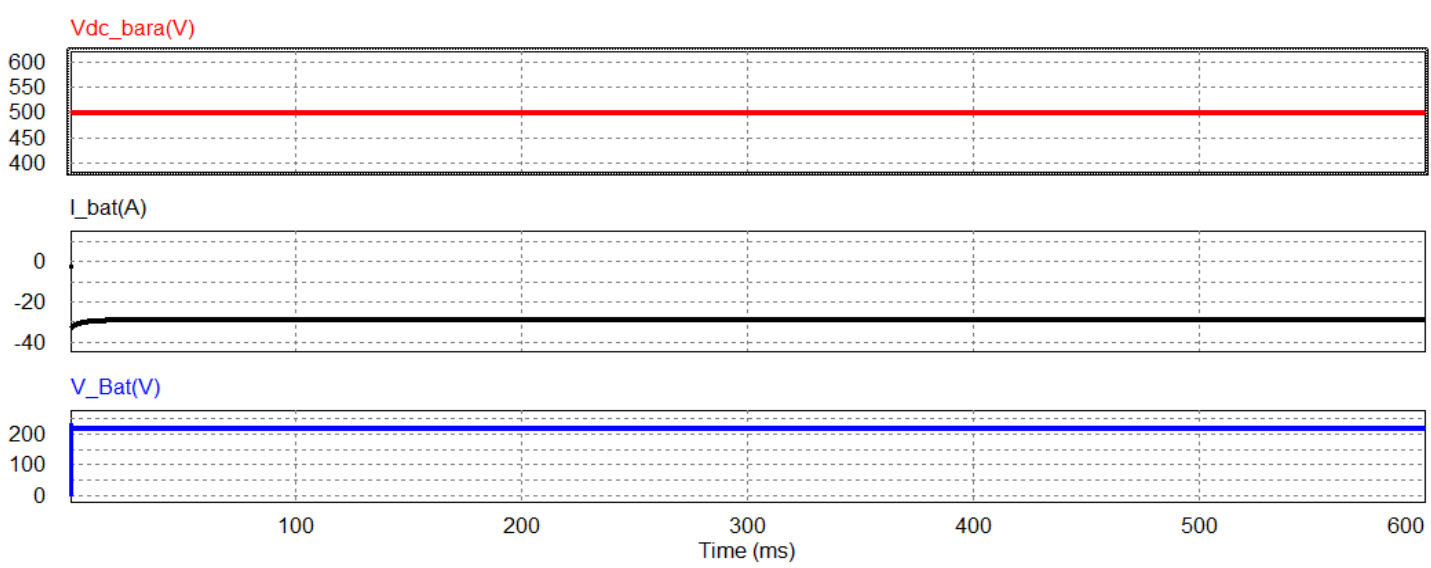

Figure 11. The simulation results of bidirectional DC-DC buck-boostconverter for battery discharge current mode

The discharge voltage mode are applied for battery. The simulation results of the PV panel supported DC-DC boost converter for battery discharge voltage mode is shown in Fig. 12. In the Fig. 12, the current of PV panel is $21.25 \mathrm{~A}$, the output voltage of PV panel is $250 \mathrm{~V}$, the output max power of PV panel is $5 \mathrm{~kW}$, the DC output voltage of boost converter is $500 \mathrm{~V}$. Fig. 13 shows simulation results of the bidirectional DC-DC buck-boost converter for battery discharge voltage mode. In the Fig. 13, the bidirectional DC-DC converter regulates the DC voltage $220 \mathrm{~V}$ in the battery $0 \mathrm{~A}$. 

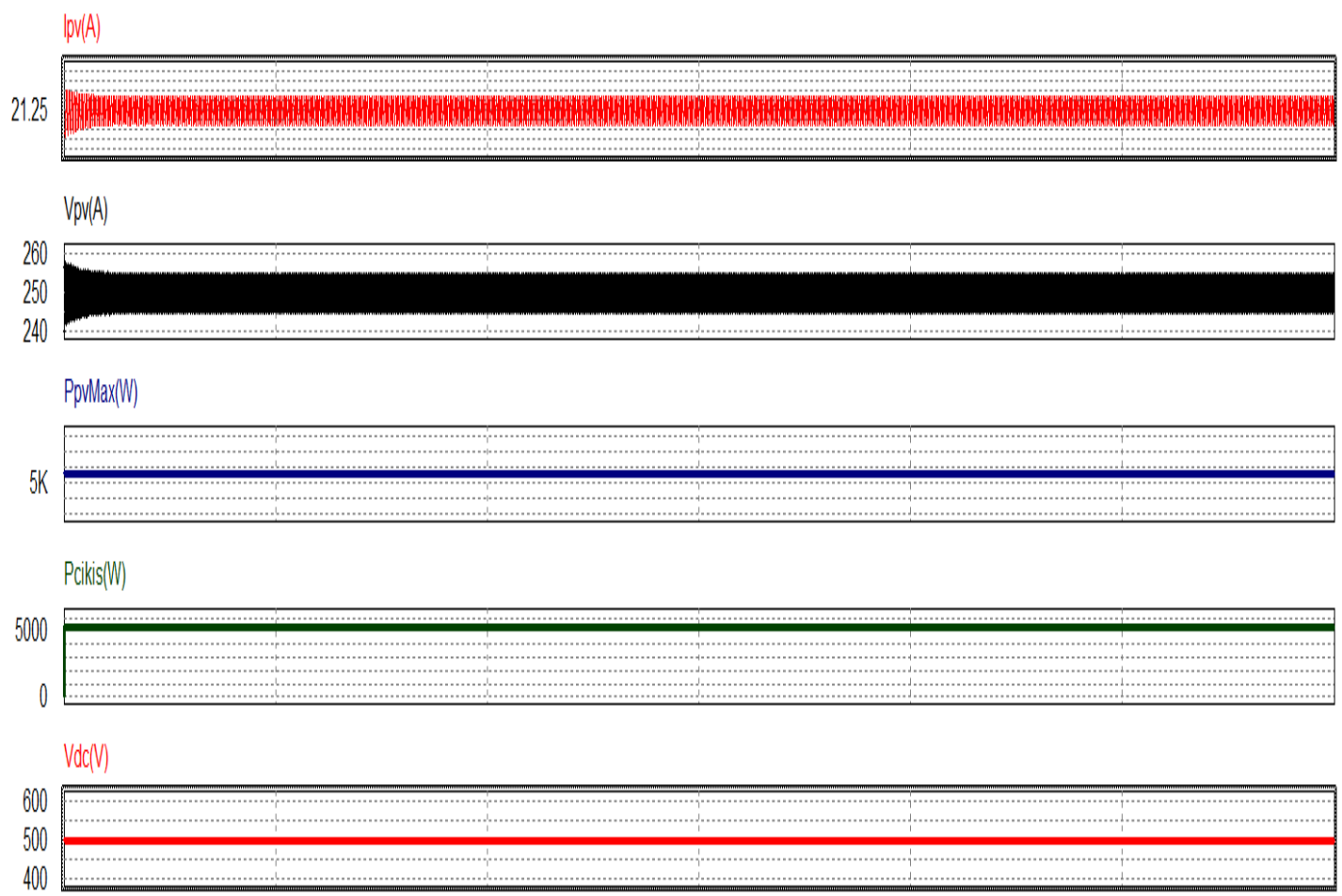

Figure 12. The simulation results for the PV panel supported DC-DC boost converter for battery discharge voltage mode

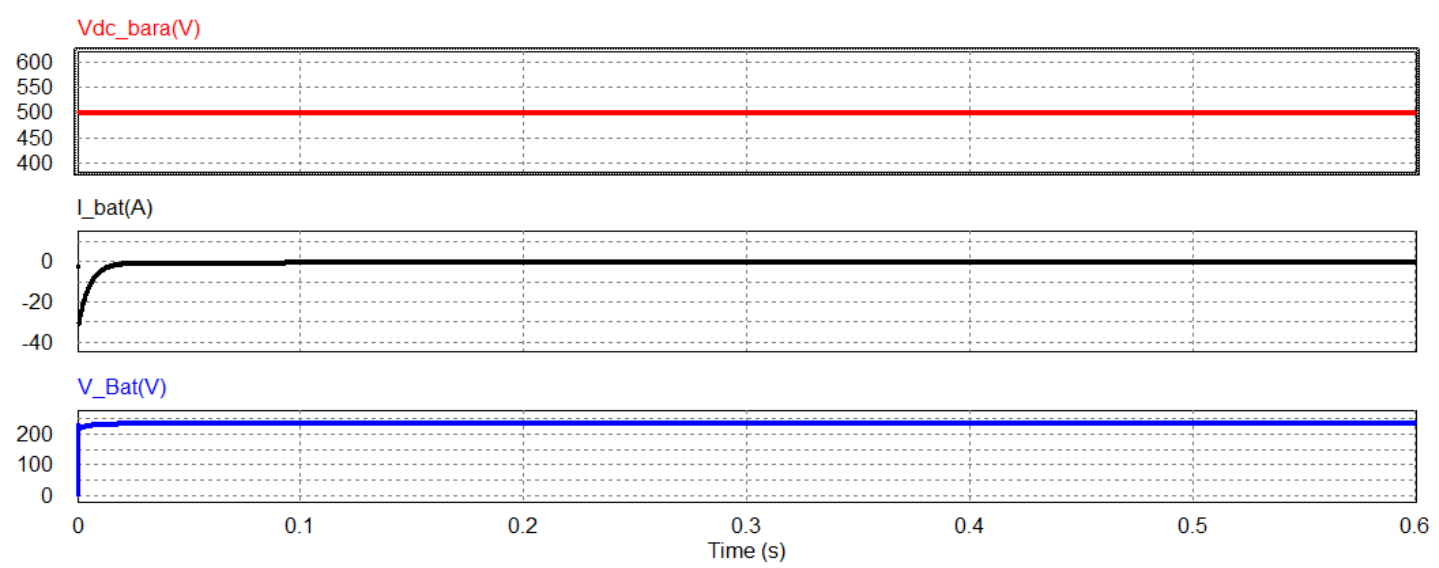

Figure 13. The simulation results of bidirectional DC-DC buck-boost converter for battery discharge voltage mode

\section{CONCLUSION}

The battery charger topology for Lion battery consists of the photovoltaic panel supported DC-DC boost converter and the half-bridge bidirectional DC-DC buck-boost converter. In the first stage, the P\&O algorithm from MPPT method is used to obtained maximum power and voltage of the photovoltaic panel (PV) system. The obtained DC voltage is $500 \mathrm{~V}$ value. In the second stage, the charge and discharge of a battery charger system is performed. The constant and voltage method with PI controller is used for bidirectional DC-DC buck-boost converter. PI controller is a simple technique and also it provides satisfactory results.

The simulation circuit of the $5 \mathrm{~kW}$ charger system is created by using of computational blocks and design suit blocks in PSIM circuit simulations. According to simulation results; $V_{p v}$ is $250 \mathrm{~V}, i_{p v}$ is $21 \mathrm{~A}, V_{d c}$ is $500 \mathrm{~V}, P_{\text {out }}$ is $5 \mathrm{~kW}$ approximately. The obtained DC voltage is applied to the bidirectional DC-DC buckboost converter. When the results of the circuit simulated, power of PV and output power of boost converter follow each other. The $\mathrm{P} \& \mathrm{O}$ controller is applied as successfully. The proposed 
charger/discharger system for Li-Ion battery can implement constant voltage or constant current charging and current mode or voltage mode discharging

\section{Acknowledgements}

This study was supported by the Bilecik Seyh Edebali University Research Fund. (No: 201502.BŞEÜ.03-09).

\section{References}

[1] Roy, C. P., Vijaybhaskar, D., \& Maity, T. (2013, December). Modelling of fuzzy logic controller for variable-step MPPT in photovoltaic system. IEEE 1st International Conference on Condition Assessment Techniques in Electrical Systems (CATCON), 341-346.

[2] Subudhi, B., \& Pradhan, R. (2012). A comparative study on maximum power point tracking techniques for photovoltaic power systems. IEEE Transactions on sustainable energy, 4(1), 8998.

[3] Bendib, B., Belmili, H., \& Krim, F. (2015). A survey of the most used MPPT methods: Conventional and advanced algorithms applied for photovoltaic systems. Renewable and Sustainable Energy Reviews, 45, 637-648.

[4] Elamathy, A., \& Vijayagowril, G. (2015, February). Multiport DC-DC interleaved boost converter supplemented by hybrid system of different capacities PV and battery power system. In 2015 2nd International Conference on Electronics and Communication Systems (ICECS), 921925.

[5] Wang, J., Botterud, A., Bessa, R., Keko, H., Carvalho, L., Issicaba, D., \& Miranda, V. (2011). Wind power forecasting uncertainty and unit commitment. Applied Energy, 88(11), 4014-4023.

[6] Noman, A. M., Addoweesh, K. E., \& Mashaly, H. M. (2012, October). A fuzzy logic control method for MPPT of PV systems. In IECON 2012-38th Annual Conference on IEEE Industrial Electronics Society, 874-880.

[7] Chim, C. S., Neelakantan, P., Yoong, H. P., \& Teo, K. T. K. (2011, March). Fuzzy logic based MPPT for photovoltaic modules influenced by solar irradiation and cell temperature. In 2011 UkSim 13th International Conference on Computer Modelling and Simulation, 376-381.

[8] Elgendy, M. A., Zahawi, B., \& Atkinson, D. J. (2011). Assessment of perturb and observe MPPT algorithm implementation techniques for PV pumping applications. IEEE transactions on sustainable energy, 3(1), 21-33.

[9] Kisacikoglu, M. C., Kesler, M., \& Tolbert, L. M. (2014). Single-phase on-board bidirectional PEV charger for V2G reactive power operation. IEEE Transactions on Smart Grid, 6(2), 767775 .

[10] Sera, D., Mathe, L., Kerekes, T., Spataru, S. V., \& Teodorescu, R. (2013). On the perturb-andobserve and incremental conductance MPPT methods for PV systems. IEEE journal of photovoltaics, 3(3), 1070-1078.

[11] Sivakumar, P., Kader, A. A., Kaliavaradhan, Y., \& Arutchelvi, M. (2015). Analysis and enhancement of PV efficiency with incremental conductance MPPT technique under non-linear loading conditions. Renewable Energy, 81, 543-550.

[12] Yilmaz, U., Kircay, A., \& Borekci, S. (2018). PV system fuzzy logic MPPT method and PI control as a charge controller. Renewable and Sustainable Energy Reviews, 81, 994-1001.

[13] Ankaiah, B., \& Nageswararao, J. (2013). Enhancement of Solar Photovoltaic Cell by Using Short-Circuit Current Mppt Method. International Journal of Engineering Sciences Invention, $2(2), 45-50$ 
[14] Kumari, J. S., \& Babu, C. S. (2011). Comparison of maximum power point tracking algorithms for photovoltaic system. International Journal of Advances in Engineering \& Technology, 1(5), 133.

[15] Chen, B. Y., \& Lai, Y. S. (2011). New digital-controlled technique for battery charger with constant current and voltage control without current feedback. IEEE transactions on industrial electronics, 59(3), 1545-1553.

[16] Jana, J., Bhattacharya, K. D., \& Saha, H. (2014). Design \& implementation of MPPT algorithm for battery charging with photovoltaic panel using FPGA. In 2014 6th IEEE Power India International Conference (PIICON), 1-5.

[17] Meena, R. (2014). Simulation study of boost converter with various control techniques. International Journal of Science and Research (IJSR), 3(9), 74-79.

[18] Mohamed, H. A., Khattab, H. A., Mobarka, A., \& Morsy, G. A. (2016). Design, control and performance analysis of DC-DC boost converter for stand-alone PV system. In 2016 Eighteenth International Middle East Power Systems Conference (MEPCON), 101-106.

[19] Hauke, B. (2009). Basic calculation of a boost converter's power stage. Texas Instruments, Application Report November, 1-9.

[20] Hua, C. C., \& Chen, Y. M. (2017). Modified perturb and observe MPPT with zero oscillation in steady-state for PV systems under partial shaded conditions. In 2017 IEEE Conference on Energy Conversion (CENCON), 5-9.

[21] Nigam, A., \& Gupta, A. K. (2016). Performance and simulation between conventional and improved perturb \& observe MPPT algorithm for solar PVcell using MATLAB/Simulink. In 2016 International Conference on Control, Computing, Communication and Materials (ICCCCM), 14. 